by comments in which the findings are surveyed and correlated with those reported for other groups of plants. Frequently, addenda contain information published in recent papers, up to 1961 .

The chemical parts are divided according to compounds like pigments, volatile oils, carbohydrates and fats, and are subdivided according to localization, for example, carbohydrates in membranes and in the extracellular space, or according to chemical principles, such as deriva. tives of phenol, resorcin, hydroquinone, pyrogallol. The great seasonal variation in the concentration of active substances is mentioned for 'Taxus, Ephedra and some other plants. Often, structural formulæ are given and metabolic pathways outlined. Occasionally, the presence of a compound and its derivatives in various groups of plants is tabulated, for example, for chryso. phanol. Biological actions are noted, some not well known, like the anthelmintic effect of algae (p. $86 \mathrm{ff}$.), the antibiotic activity of purine derivatives ( $p .143$ ) and of certain kinds of moss (p. 189), and the fall in blood pressure caused by a chemically unidentified alkaloid from the root of Ephedra (p. 459).

Both morphological classification of plants and the grouping of phytochemical data meet with great problems. For example, Cronquist considers that the classification of the plant kingdom adopted in this work has outlived its usefulness and is now disappearing from the text-books. The relevant chemical literature, too, varies in its approach as the biogenesis of plant constituents is widely studied and the concept of chemical races developed. This book is a welcome source of information to those interested in botany, pharmacognosy, pharmacology and biochemistry. L. WISLICKI

\section{A SURVEY OF PALESTINE'S VEGETATION}

\section{Plant Life of Palestine}

Israel and Jordan. By Prof. Michael Zohary. ("Chronica Botanica" : New Series of Plant Science Books, No. 33.) Pp. $x i+262$. (New York : The Ronald Press Company, 1962.) 8 dollars.

$\mathrm{T}$

$O$ write $a$ balanced and succinct account of the vegetation of Palestine is probably one of the most difficult tasks that can confront an ecologist. Even in its pristine, undisturbed condition, a country with such diverse topographic, edaphic and climatic features must have exhibited complex vegetation patterns; but when one super-imposes roughly ten thousand years of varied and intermittent interference by man and his beasis, then Nature and artifice combine to produce a situation which almost defies analysis.

What the pristine vegetation of Palestine was really like will probably never be known with certainty, but this in no way derogates from the value of an observant naturalist's deductions. For this reason, everyone who is interested in the vegetation of the eastern Mediterranean and the Near East will welcome Prof. Zohary's book, which, it must be added, fully acknowledges all the difficulties, and outlines the present characteristics of Palestine plant-life, and its possible antecedents, with commendable impartiality and restraint. It is also very much to the author's credit that he has been able to view the subject from so many aspects, in the space of so few pages, without loss of clarity.

Topography, soils, climate, floristics, life-forms and all the more important plant-societies of Palestine are dealt with in considerable detail, and, for good measure, we are then offered valuable, and very instructive, chap. ters on ecological behaviour, and on the relationships of man with the vegetation, all this rounded off with an excellent list of references and index. One might wish, perhaps, that Prof. Zohary had relaxed a little, and freed himself a little more from the strait-jacket of Continental phytosociology. $\mathrm{H}_{\theta}$ is at his best when recording plain facts and personal observations-the unexpected dormancy of deciduous trees during the most favourable season for growth; the anomalous behaviour of the carob tree, or the failure of tall trees and bushes to invade protected areas of batha and garigue-and one hopes that his successful completion of this book will now encourage him to set about writing a more leisurely. contemplative one, with ample digressions on the quirks and oddities of plant behaviour in Palestine, and specula. tions on the history and relationships of Palestine plants and plant associations. Such scientific ruminations would be a valuable supplement to the factual austerities of the present volume, and, coming from one with such extensive field experience in the Palestine area, would be an important contribution to that remote but most alluring of goals-an all-embracing survey of Mediterranean vegetation and its history. R. D. MEIKLE

\section{MYTHOLOGY OF THE ORIENT}

\section{Oriental Mythology}

The Masks of God, Vol. 2. By Joseph Campbell. Pp. $\mathrm{x}+$ $561+23$ illustrations. (I condon: Secker and Warburg,
1962 .) $50 s$.

F Volume 1 of The Masks of God, adversely reviewed in Nature $(187,7 ; 1960)$, was an unsatisfactory hotch-potch, with this second volume Dr. Campbell executes a tour de. force. Concerned now with the mythologies of the great eivilizations of India, China and Japan, Dr. Campbell has plenty of literary, historical and archæological evidence to guide him in identifying what he most happily calls the mythological 'signatures' of these civilizations. No longer basing his argument on supposition, pseudobiology, and inadequate ethnographic reports, he moulds his analysis consistently on the firmer ground of "social representation'. His main point is to show how, as much to-day as in the past, the East is dominated by monistic thought: the individual, a monad or parcel of monads, is but an illusory projection of the social or moral order on one hand, and the divine order on the other. Indeed, the individual only begins to be relevant when merged with the void, when nothing becomes nothing.

In Western eyes this last is more than a paradox: it is a contradiction without meaning. 'Quite so!' the Easterner might comment: and the gulf botween different modes of understanding remains. In contrasting this Eastern 'signature' with the Western-where the notion of the individual bestrides the world-Dr. Campbell seems to attempt, rather uneasily, to bridge the gulf. Since both modes of thought had a common source-in Sumer, that first of all flights into the civilized condition-he seems to say, and since, through several millennia, the civilizations of the East have flowered because of fertilizing influences from the West, a rapprochement is possible. Perhaps. Certainly this volume in itself could be a step away from Kipling's dictum.

One says 'could be' rather than 'is' because, though the reader will find this book a mine of information, not only are syntheses such as this two-edged and inherently vulnerable to attacks from many quarters, but also this particular volume is both too long and too short. The former because the central statement is apt to be lost in a plethora of detail and a rather diffuse style, and the latter because specialists will quarrel at the use and interpretations of their particular contributions. Nevertheless, here is a book worth reading and worth keeping for dipping into. One looks forward to Volume 3, which is to consider Western mythologies, and then-may on? hope for a brief and concise statement?

K. O. L. BURRIDGE: 